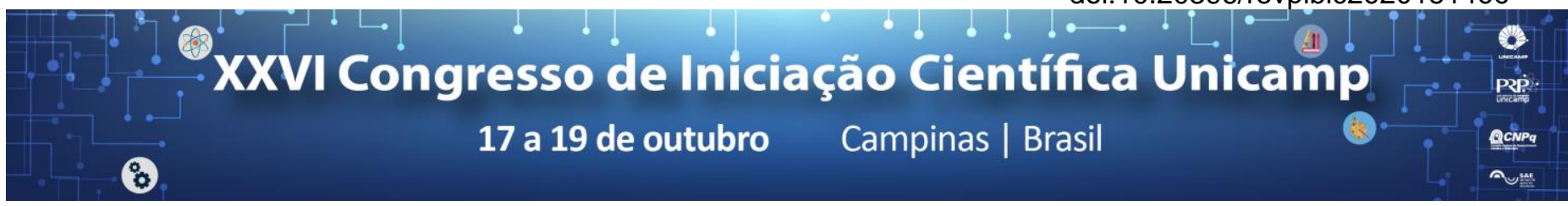

\title{
DESENVOLVIMENTO DE UM ROBÔ SEGUIDOR DE LINHA UTILIZANDO ARDUINO UNO
}

\section{Ana Paula Gomes de Carvalho*, Danielle Antunes Teixeira*, Vinicius de Souza Lima*, Rodrigo Luiz Ximenes, Talía Simões dos Santos.}

\section{Resumo}

O projeto propõe a elaboração de um robô seguidor de linha utilizando Arduino Uno desde as etapas primordiais, como o desenvolvimento e construção do chassi que dá base ao robô e a elaboração da parte mecânica e eletrônica dele, além do desenvolvimento da programação que permite o funcionamento do seguidor de linha.

\section{Palavras-chave:}

Microcontrolador, sensores, robótica.

\section{Introdução}

Os estudos na área de robótica é algo que vem crescendo muito no mundo e no Brasil. Nas indústrias, as tarefas antes realizadas por homens, foram facilitadas com o uso de meios robóticos, que podem executar tarefas pré programadas sem a interferência humana. Robôs seguidores de linha são pequenos robôs que funcionam a partir de um princípio onde podem se locomover e se orientaram de maneira autônoma. Isso se torna possível através da utilização de sensores que funcionam baseadas em programações.

O projeto foi realizado com o objetivo de desenvolver um robô seguidor de linha utilizando o microcontrolador Arduino UNO. Sendo possível assim, introduzir os membros do projeto a área da robótica, dando uma noção prática dos processos envolvidos na produção de um seguidor de linha, desde a determinação e construção do chassi, até a programação do utilizada.

\section{Resultados e Discussão}

Para a produção do robô seguidor de linha utilizamos: sensores infra-vermelhos (Figura 1), servo motor, Arduino Uno, ponte $\mathrm{H}$, bateria, rodas de tração, dois motores $\mathrm{DC}$ e chassi impresso em PLA.

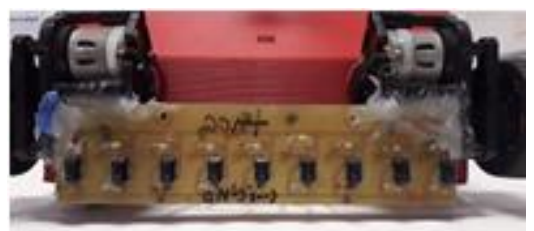

Figura 1. Imagem dos sensores infra-vermelhos.

Com a realização do trabalho em suas diversas etapas, obtivemos resultados satisfatórios.

Após a determinação da geometria do chassi foi inciada sua criação utilizando AutoCad em seu desenho e após isso, foi feita a impressão do mesmo em uma impressora 3D.

Com a etapa de construção concluída, passamos para a etapa onde introduzimos toda a parte elétrica e eletrônica do robô, com a colocação das rodas de tração e também a roda boba traseira, além de fazer todas as instalações elétricas como a colocação da bateria e introdução da ponte $\mathrm{H}$ para o chaveamento dos motores e por fim foram feitas todas as ligações com o Arduino.
Com o robô pronto, foi implementada a programação dos sensores e efetuados os testes práticos do robô como mostram as imagens abaixo (Figura 2).
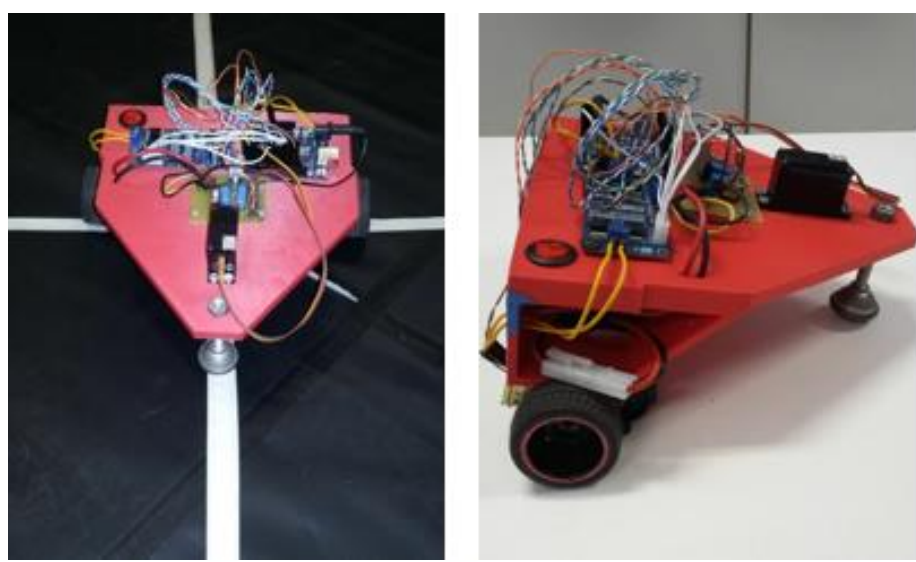

Figura 2. Imagens do robô seguidor de linha pronto.

\section{Conclusões}

Com a realização do projeto, conseguimos adquirir conhecimentos básicos em relação a área de robótica, os quais foram necessários para o desenvolvimento das diversas etapas envolvidas na execução do projeto. Isso permitiu que as etapas não-teóricas do projeto pudessem ser executadas e concluídas. Essa compreensão de cunho teórico sobre o tema do projeto possibilitou que o mesmo fosse concluído com sucesso, alcançando o objetivo maior do trabalho que era a elaboração de um seguidor de linha. Com isso, podemos observar e concluir sobre a importância do projeto na obtenção de conhecimento teórico e prático, mesmo que de maneira básica sobre a área de elaboração de robôs que está presente das mais variadas formas no nosso dia-a-dia e que é tão crescente atualmente.

\section{Agradecimentos}

Agradecemos o aluno de Eng. de Telecomunicações André Henrique do Nascimento Cruz pelos auxílios na parte final do projeto.

\footnotetext{
${ }_{1}$ Amorim, A. R.. Robô seguidor de linha autônomo utilizando o controlador proporcial-derivativo em uma plataforma de hardware / software livre. 2001. 2 Rampim, J.. Apostila de Desenho. Parte do Programa: Primeira série. 2017, Cotil, Unicamp, Limeira - SP.
} 